\title{
ANALISIS FAKTOR-FAKTOR YANG MEMPENGARUHI KINERJA BANK (STUDI PADA BANK UMUM YANG TERDAFTAR DI BEI TAHUN 2016-2020)
}

\author{
${ }^{1}$ Dwi Epty Hidayaty \\ ${ }^{2}$ Didit Supriyadi \\ ${ }^{3}$ Robby Fauji \\ ${ }^{1}$ Program Studi Manajemen, Fakultas Ekonomi dan Bisnis, Universitas Buana Perjuangan \\ Karawang \\ ${ }^{2}$ Program Studi Manajemen, Fakultas Ekonomi, Universitas Singaperbangsa Karawang \\ ${ }^{3}$ Program Studi Manajemen, Fakultas Ekonomi dan Bisnis, Universitas Buana Perjuangan \\ Karawang
}

\begin{abstract}
Email: dwi.epty@ubpkarawang.ac.id ${ }^{1}$, didit.supriyadi@fe.unsika.ac.id ${ }^{2}$, robby.fauji@ubpkarawang.ac.id ${ }^{3}$
\end{abstract}

\begin{abstract}
ABSTRAK
Penelitian ini bertujuan untuk menguji faktor-faktor yang mempengaruhi kinerja bank yang terdaftar di Bursa Efek Indonesia. Faktor-faktor tersebut adalah Efisiensi Operasi (BOPO), Net Interest Margin (NIM), Loan to Deposit (LDR), dan Non Performance Loan (NPL) Terhadap Kinerja Bank Return On Asset (ROA). Data yang digunakan dalam penelitian ini diperoleh dari Laporan Keuangan Publikasi Perusahaan Perbankan yang terdaftar di BEI. Berdasarkan metode Purposive Sampling, sampel yang digunakan sebanyak 32 perusahaan Perbankan dengan kriteria antara lain: perusahaan perbankan tersebut terdaftar di Bursa Efek Indonesia (BEI) dan memberikan data laporan keuangan selama periode 2016-2020. Jenis data yang digunakan adalah data sekunder, yang merupakan gabungan dari data time series. Metode analisis yang digunakan regresi linier berganda dengan data panel yang diolah menggunakan SPSS. Hasil penelitian menunjukan bahwa variabel BOPO berpengaruh negatif signifikan terhadap ROA, NIM berpengaruh positif signifikan terhadap ROA, sedangkan LDR tidak berpengaruh signifikan terhadap ROA, dan NPL berpengaruh negatif tidak signifikan terhadap ROA.
\end{abstract}

Kata kunci: Kinerja Bank, Efisiensi Operasi, Risiko Pasar, Likuiditas, Risiko Kredit

ABSTRACT

This study aims to examine the factors that affect the performance of banks listed on the Indonesia Stock Exchange. These factors are Operational Efficiency (BOPO), Net Interest Margin (NIM), Loan to Deposit (LDR), and Non Performance Loan (NPL) on Bank Performance Return On Assets (ROA). The data used in this study were obtained from the Published Financial Statements of Banking Companies listed on the IDX. Based on the purposive sampling method, the sample used is 32 banking companies with the following criteria: the banking companies are listed on the Indonesia Stock Exchange (IDX) and provide financial statement data for the 2016-2020 period. The type of data used is secondary data, which is a combination of time series data. The analytical method used is multiple linear regression with panel data processed using SPSS. The results showed that the BOPO variable had a significant negative effect on ROA, NIM had a significant positive effect on ROA, while LDR had no significant effect on ROA, and NPL had an insignificant negative effect on ROA.

Keywords: Bank Performance, Operational Efficiency, Market Risk, Liquidity, Credit Risk 


\section{PENDAHULUAN}

Pertumbuhan ekonomi global yang kian tahun semakin marak dengan merambahnya berbagai pertumbuhan di segala aspek bisnis. Dan terjadi kondisi persaingan dagang antara negara Amerika dengan negara Tiongkok. Berbekal dukungan penuh dari seluruh pihak, Indonesia pun bersiap memasuki era percepatan pertumbuhan ekonomi saat ini, salah satunya yaitu pada sektor finansial dan perbankan. Seiring berkembangnya dunia perbankan terkini dengan melihat segala bentuk penguasaan dan adaptif terhadap perkembangan teknologi yang digunakan oleh perusahaan untuk mendukung kegiatan operasional perusahaan menjadi lebih efektif dan efisien, karena dapat menyederhanakan, mempermudah dan mengontrol proses dengan sumber daya manusia yang terbatas.

Kesulitan lembaga perbankan di Indonesia tampak berkepanjangan, padahal Bank Indonesia telah menjalankan tugasnya sebagai Lender of last resort, yaitu fungsi yang melekat sebagai pelindung bank dalam hal terjadi kesulitan likuiditas (Taswan, 2010). Oleh karena itu, penting bagi kita semua untuk mempelajari setiap aspek yang terkait dengan pelaku utama dalam sistem keuangan, yaitu perbankan.

Selain adanya pembaharuan di bidang teknologi yang digunakan, perbankan juga menetapkan tata nilai perusahaan dengan beragam kepentingan, baik itu dari pihak stakeholder maupun seluruh pelaku pasar dan lapisan masyarakat yang kerap kali berinteraksi dengan dunia perbankan. Tata nilai perusahaan yang baik dapat dipertahankan perusahaan yaitu yang terdiri dari kerja tim, integritas, profesionalisme dan service excellence yang utama pada bisnis perbankan. Karena pada dasarnya dalam bisnis perbankan adalah bagaimana perusahaan dapat meningkatkan kinerjanya, baik kepada nasabah sebagai customer suatu perusahaan yang menjadi tolak ukur baik/buruknya suatu pelayanan karena adanya customer satisfaction, maupun kepada para investor yang cakap dalam memilih bank manakah yang akan dijadikan tempat untuk berinvestasi bagi keamanan bisnisnya.

Seperti yang sudah dikemukakan oleh Didik Purwoko (2013) dalam jurnalnya dimana peranan perbankan saat ini sangat dominan dalam sistem keuangan, sehingga pemahaman dan pengelolaan Bank yang baik tentunya akan mendorong sistem keuangan yang baik. Apalagi kemudian pemahaman kita diperkaya dengan berbagai pemaparan mengenai pengelolaan rasio keuangan, penilaian kinerja dan tingkat kesehatan yang memadai. Berangkat dari pemikiran tersebut lingkup materi tentang anlisis rasio keuangan perbankan dirasakan masih sangat dibutuhkan dan diupayakan demi kepentingan semua pihak. Hal yang sama juga dikemukakan oleh Wawan Prasetyo (2015) bahwa dengan melihat dan memahami pentingnya profitabilitas 
perbankan dan perusahaan sebagai tujuan utama dari suatu perbankan atau perusahaan, maka harus benar-benar diperhatikan secara serius kinerja profitabilitas.

Profitabilitas bank diukur dengan menggunakan ROA (Return On Asset). Faktor penentu profitabilitas dapat dilihat dari faktor internalnya yang meliputi kecukupan modal, efisiensi operasional, likuditas dan ukuran aset. Karena dari faktor internal menggambarkan kondisi bank dan kinerja bank selama menjalankan aktifitasnya sebagai lembaga intermediasi. Gambaran mengenai kinerja bank dapat dilihat dari laporan keuangan yang bersangkutan. Dalam penelitian ini terdapat rasio-rasio yang dipergunakan untuk menilai tingkat kesehatan bank yaitu rasio BOPO, NIM, LDR, NPL, dan Profitabilitas. Dalam upaya meningkatkan pertumbuhan ekonomi dan kesejahteraan masyarakat, pemerintah menyadari bahwa peranan bank sangat penting. Bank merupakan sebuah lembaga atau perusahaan yang aktivitasnya menghimpun dana berupa giro, deposito tabungan dan simpanan yang lain dari pihak yang kelebihan dana (surplus spending unit), kemudian menempatkannya kembali kepada masyarakat yang membutuhkan dana (deficit spending unit) melalui penjualan jasa keuangan yang pada gilirannya dapat meningkatkan kesejahteraan rakyat banyak (Taswan, 2010). Dunia usaha dalam menjalankan usahanya tidak lepas dari dukungan bank, baik peranan bank sebagai peranan dalam lalu lintas pembayaran, penghimpun dana maupun penyalur dana (Kuncoro dan Suhardjono, 2002).

Perkembangan dan pembangunan ekonomi disuatu negara juga sangat bergantung pada perkembangan dinamis dan kontribusi nyata dari sektor perbankan. Bank Umum (Commercial Bank) memiliki peranan yang sangat penting dalam menggerakkan roda perekonomian nasional, karena Dana Pihak Ketiga (DPK) perbankan nasional yang meliputi Bank Umum (Commercial Bank), Bank Syariah (Sharia Bank), dan Bank Perkreditan Rakyat (Rural Bank) berada di Bank Umum. DPK ini yang selanjutnya digunakan untuk mendorong pertumbuhan ekonomi melalui penyaluran dana kredit. Penyaluran dana kredit dapat membantu masyarakat dalam melakukan berbagai kegiatan ekonomi yang berkontribusi terhadap pembangunan perekonomian masyarakat.

Namun pada kenyataannya, masih ada beberapa perusahaan perbankan ataupun lembaga keuangan lainnya yang berada di Indonesia belum siap menghadapi era digitalisasi yang sudah berjalan di perekonomian dunia. Oleh karena itu seiring berjalannya waktu pada era transformasi ini, terdapat beragam fitur dan fasilitas perbankan yang ditawarkan yang mewakili interest dan gaya hidup dari segmen pasarnya dan menggunakan kecanggihan teknologi, dengan sistem digitalisasi. 
Usaha bank bukan saja sebagai penghimpun dan penyalur dana, tetapi juga pencipta alat-alat pembayaran, stabilisasi moneter dan dinamisator pertumbuhan perekonomian suatu negara. Bahkan bank mendorong terjalinnya hubungan perekonomian perdagangan

internasional antar negara di dunia. Setiap perusahaan memanfaatkan jasa-jasa perbankan,

karena kelancaran lalu lintas pembayaran dan penagihan hanya dapat dilakukan dengan memanfaatkan jasa perbankan (Didik Purwoko, 2013). Profitabilitas merupakan indikator yang paling tepat untuk mengukur kinerja suatu bank (Syofyan, 2002). Ukuran profitabilitas pada industri perbankan yang digunakan pada umumnya adalah Return On Equity (ROE) dan Return On Asset (ROA). Return On Asset (ROA) memfokuskan kemampuan perusahaan untuk memperoleh earning dalam opersasinya, sedangkan Return On Equity (ROE) hanya mengukur return yang diperoleh dari investasi pemilik perusahaan dalam bisnis tersebut (Siamat, 2002). Untuk selanjutnya dalam penelitian ini menggunakan ROA sebagai ukuran kinerja perbankan.

Dalam penelitian ini selain menguji faktor-faktor yang menentukan kinerja bank yang listed di Bursa Efek Indonesia, juga ada banyak faktor yang mempengaruhi kinerja bank, baik faktor internal maupun faktor external bank. Dimana faktor dari dalam dapat dikendalikan manajemen, sedangkan faktor dari luar tidak dapat dikendalikan manajemen. Penelitian ini menguji faktor-faktor dari dalam yang mempengaruhi kinerja bank terkait pada rentabilitas dan profitabilitas perbankan. Faktor-faktor tersebut diantaranya adalah Efisiensi Operasi (BOPO), Risiko Pasar (NIM), Likuiditas (LDR) dan Risiko Kredit (NPL). Seberapa besar efisiensi operasi, risiko pasar, likuiditas dan risiko kredit, mempengaruhi kinerja bank (ROA)

Dari laporan kinerja keuangan perbankan yang di publikasikan di Bursa Efek Indonesia, peneliti menampilkan gambaran pertumbuhan dari kinerja Bank dengan data ROA per Desember 2020:

\section{Gambar 1.2 Kinerja Bank Umum}

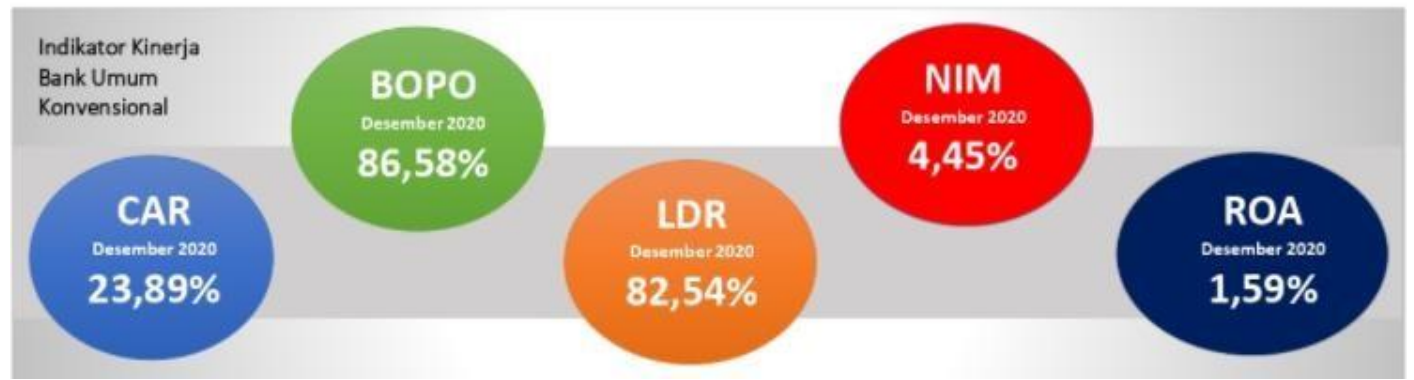

Sumber: diolah dari Statistik Perbankan Indonesia 
Melalui salah satu faktor yakni dengan BOPO di tahun terakhir yaitu tahun 2020 rate nya mencapai $86,58 \%$, maka dapat diasumsikan bahwa semakin besar biaya yang dikeluarkan dengan rate BOPO yang meningkat, apakah nantinya sebanding dengan profitabilitas yang didapatkan perusahaan perbankan, bisa kita lihat dari hasil pengujian faktor tersebut termasuk didalamnya ada faktor-faktor penentu lainnya yang akan mempengaruhi dalam penelitian ini.

Hal ini menjadi daya tarik yang mendorong peneliti untuk melakukan analisis dari fenomena diatas selain bertujuan melakukan kajian empiris terhadap faktor-faktor yang mempengaruhi kinerja perbankan. Dengan kondisi yang demikian, maka dilakukan penelitian tentang "Analisis faktor-faktor yang mempengaruhi Kinerja Bank (Studi pada Bank Umum yang terdaftar di Bursa Efek Indonesia Tahun 2016-2020)”.

\section{METODE PENELITIAN}

\section{Jenis Penelitian}

Penelitian ini merupakan penelitian kuantitatif dengan jenis metode deskriptif verifikatif, menggunakan alat analisis regresi linier berganda (multiple regression analysis) guna mengetahui arah, pengaruh, dan kekuatan hubungan dari variabel independen terhadap variabel dependen. Dengan sampel sebanyak 32 perusahaan Perbankan dengan kriteria antara lain: perusahaan perbankan tersebut terdaftar di Bursa Efek Indonesia (BEI), dan memberikan data laporan keuangan yang digunakan untuk menganalisis faktor-faktor yang mempengaruhi kinerja bank dengan studi pada bank umum yang terdaftar di Bursa Efek Indonesia periode 2016 - 2020, dalam hal ini adalah yang bertujuan kepada profitabilitas dengan kinerja bank (ROA), menggunakan metode rasio-rasio yang menjadi faktor-faktor yang mendukung dalam pencapaiannya yaitu Efisiensi Operasi (BOPO), Risiko Pasar (NIM), Likuiditas (LDR) dan Risiko Kredit (NPL). Dimana pada penelitian ini akan mengkaji lebih dalam tentang keterkaitan ataupun pengaruh dari BOPO, NIM, LDR dan NPL terhadap variabel dependennya yaitu kinerja bank yang diproksikan dengan ROA.

\section{Waktu dan Tempat Penelitian}

Penelitian ini dilakukan pada awal tahun 2021, dimana untuk pengambilan data yang digunakan penelitian merupakan data sekunder Bank Umum di Indonesia yang diperoleh dari Laporan Keuangan Publikasi Perusahaan Perbankan pada Bursa Efek Indonesia periode Tahun 2016 - 2020 yang merupakan gabungan dari data time series atau cross section. Kantor Bursa Efek Indonesia yang bertempat di Indonesia Stock Exchange Building, 1st Tower 
$\mathrm{Jl}$.

Jend.

Sudirman

Kav

Jakarta Selatan 12190, Indonesia melalui website www.idx.co.id dan www.ojk.go.id Target/Subjek Penelitian

Target sasaran penelitian atau subjek penelitian ini pada bank umum yang beroperasi dan mempunyai kantor pusat di Indonesia yaitu bank yang go public yang telah terdaftar di Bursa Efek Indonesia tahun 2016-2020.

Sampel yang diambil berdasarkan pemilihan sampel bertujuan (Purposive Sampling) dan metode pemilihan sampel berdasarkan pertimbangan (Judgement Sampling) yakni pengambilan sampel didasarkan pada penilaian terhadap beberapa karakteristik anggota sampel yang disesuaikan dengan maksud penelitian (Mudrajad Kuncoro, 2003:119). Sampel sebanyak 32 perusahaan Perbankan dengan kriteria antara lain: perusahaan perbankan tersebut terdaftar di Bursa Efek Indonesia (BEI), dan memberikan data laporan keuangan yang digunakan untuk menganalisis faktor-faktor yang mempengaruhi kinerja bank dengan studi pada bank umum yang terdaftar di Bursa Efek Indonesia periode 2016-2020, dalam hal ini adalah kinerja bank (ROA) dengan tujuan profitabilitas, menggunakan faktor-faktor yang mendukung dalam pencapaiannya yaitu BOPO, NIM, LDR dan NPL.Data yang telah dikompilasi menunjukkan bahwa terdapat 32 bank sebagai jumlah sampel yang diambil dalam penelitian ini yaitu bank umum yang telah terdaftar di Bursa Efek Indonesia.

\section{Prosedur Penelitian}

Dari permasalahan yang ada, maka akan diteliti dan sesuai dengan tema dalam penelitian ini yaitu analisis faktor-faktor yang mempengaruhi kinerja bank (studi pada bank umum yang terdaftar di BEI Tahun 2016-2020). Sedangkan untuk alat analisis yang digunakan yaitu dengan analisis linier berganda berupa laporan keuangan bank dan yang menjadi subvariabelnya adalah $\mathrm{X}_{1}, \mathrm{X}_{2}, \mathrm{X}_{3}$, dan $\mathrm{X}_{4}$ terhadap $\mathrm{Y}$ pada rasio-rasio keuangan, yang menjadi indikatornya adalah untuk Y adalah Kinerja bank (ROA), $\mathrm{X}_{1}$ yaitu Efisiensi Operasi (BOPO), untuk $\mathrm{X}_{2}$ yaitu Risiko Pasar (NIM), untuk $\mathrm{X}_{3}$ yaitu Likuiditas (LDR), dan untuk $\mathrm{X}_{4}$ yaitu Risiko Kredit (NPL).

\section{Operasionalisasi Variabel}

\section{Definisi Konseptual dan Definisi Operasional}

Variabel dalam penelitian ini adalah kinerja perusahaan yang diproksi dengan Return on Asset (ROA) sebagai variabel dependen. Sedangkan variabel independennya adalah Efisiensi Operasi yang diproksi dengan variabel BOPO, Risiko Pasar yang diproksi dengan variabel NIM, Likuiditas yang diproksi dengan variabel LDR, dan Risiko Kredit, yang diproksi dengan variabel NPL. Masing-masing variabel dapat dijelaskan sebagai berikut: 


\section{a. Return on Asset (ROA)}

Return on asset merupakan perbandingan antara laba sesudah pajak dengan total aset yang dimiliki. Semakin besar nilai ROA, maka semakin bagus pula kinerja perusahaan perbankan tersebut, karena return yang didapatkan perusahaan semakin besar.

$$
\text { ROA }=
$$

Total Asset

\section{b. Biaya Operasional Terhadap pendapatan Operasional (BOPO)}

Biaya operasional terhadap pendapatan operasional merupakan perbandingan antara beban operasional dengan pendapatan operasional. Beban operasional dihitung berdasarkan penjumlahan dari total beban bunga dan total beban operasional lainya. Sedangkan pendapatan operasional merupakan penjumlahan dari total pendapatan bunga dan total pendapatan operasioanl lainya. Semakin tinggi rasio ini menunjukan semakin tidak efisien biaya operasional bank.

$$
\mathrm{BOPO}=\frac{\text { Total Beban Operasional }}{\text { Total Pendapatan Operasional }}
$$

\section{c. Net Interest Margin (NIM)}

Net interest margin merupakan perbandingan antara pendapatan bunga bersih terhadap ratarata aktiva produktif. Rasio ini mengindikasikan kemampuan bank menghasilkan pendapatan bunga bersih dengan penempatan aktiva produktif. Semakin besar rasio ini semakin baik kinerja bank dalam menghasilkan pendapatan bunga. Namun harus dipastikan bahwa ini bukan karena biaya intermediasi yang tinggi, asumsinya pendapatan bunga harus ditanamkan kembali untuk memperkuat modal bank.

Pendapatan Bunga Bersih

$\mathrm{NIM}=$

Rata-Rata Aktiva Produktif

\section{d. Loan to Deposit Ratio (LDR)}

Merupakan perbandingan kredit yang diberikan terhadap dana pihak ketiga (Giro, Tabungan, Sertifikat Deposito dan Deposito). Semakin besar rasio ini 
mengindikasikan bank itu semakin agresif likuiditasnya, sebaliknya semakin kecil rasio ini juga semakin besar dana pihak ketiga yang tidak digunakan untuk penempatan ke kredit. Rasio LDR juga merupakan rasio yang digunakan untuk mengukur kemampuan bank dalam memenuhi pembayaran kembali deposito yang telah jatuh tempo kepada deposanya, serta dapat memenuhi permohonan kredit yang diajukan tanpa terjadi penangguhan.

$$
\text { LDR }=\frac{\text { Total Kredit }}{\text { Total dana Pihak Ketiga }}
$$

e. Non Performance Loan (NPL)

Non Performance Loan merupakan perbandingan antara kredit bermasalah terhadap total kredit. Rasio ini mengindikasikan bahwa semakin tinggi rasio NPL menunjukan semakin buruk kualitas kreditnya.

Total Kredit Bermasalah

$\mathrm{NPL}=$

Total Kredit

\section{Data, Instrumen, dan Teknik Pengumpulan Data}

Sumber data penelitian menggunakan data sekunder dari BEI dimana sumber datanya merupakan data yang tidak langsung memberikan data kepada pengumpul data. Penelitian ini menggunakan data laporan keuangan perbankan publikasi yang terdiri dari rasio keuangan perbankan pada bank umum yang terdaftar di Bursa Efek Indonesia untuk periode 2016-2020 melalui website www.idx.co.id dan www.ojk.go.id.

Untuk teknik pengumpulan datanya dalam memperoleh data dalam pembuatan tesis ini dengan teknik sebagai berikut:

1. Studi kepustakaan, dimana menggunakan data dari buku-buku, literasi dan sumbersumber data lainnya yang berhubungan dengan objek pembahasan.

2. Observasi sebagai teknik pengumpulan data yaitu dengan cara menggunakan teknologi internet untuk mencari data-data yang dibutuhkan dalam penelitian.

\section{Teknik Analisis Data}

Sebelum melakukan pengujian hipotesis, diperlakukan pengujian validitas dan reliabilitas terhadap indikator atau pertanyaan-pertanyaan kuesioner dengan menggunakan SPSS. Nilai yang digunakan untuk menentukan kevalidan item adalah pada corrected item- 
total correlation. Apabila nilainya $>\mathrm{r}_{\mathrm{tabel}}$, maka item valid. Keajegan dalam cronbach alpha harus $>$ dari $r_{\text {tabel }}$ indentifikasi bahwa reliabitas cukup. Penelitian ini menggunakan data sekunder, maka untuk menentukan ketepatan model perlu dilakukan pengujian atas beberapa asumsi klasik yang digunakan dalam penelitian ini. Pengujian asumsi klasik dilakukan dengan melakukan uji normalitas, uji heteroskedastisitas, uji multikolinieritas, dan uji auto korelasi. Sebelum pengujian asumsi klasik dilakukan, terlebih dahulu akan dilakukan pengujian normalitas errors. Pengujian normalitas bertujuan untuk mengetahui apakah dalam model regresi, variabel pengganggu atau residual memiliki distribusi normal. Hal ini dilakukan mengingat bahwa uji t dan F mengasumsikan bahwa nilai residual mengikuti distribusi normal.

\section{Uji Normalitas}

Hasil uji normalitas ini dapat dilihat dengan melihat distribusi residual dari model regresi. Pengujian normalitas dilakukan dengan menghitung nilai Zskewness, dimana nilai Zskewness berada pada \pm 1.96 .

Berdasarkan perhitungan nilai Z unstandardized residual bisa diketahui nilai Zskewness berada pada \pm 1.96 . jadi dapat dikatakan bahwa variabel pengganggu atau residual terdistribusi normal. Apabila tingkat signifikansi lebih besar dari nilai $\alpha(5 \%)$ maka dapat dikatakan bahwa residual sudah terdistribusi secara normal. Namun apabila sebaliknya tingkat signifikansi lebih kecil dari nilai $\alpha(5 \%)$, maka dapat dikatakan bahwa residual belum terdistribusi secara normal.

\section{Uji Autokorelasi}

Uji autokorelasi bertujuan untuk menguji apakah dalam suatu model regresi linier ada korelasi antar kesalahan pengganggu pada periode (t) dengan kesalahan pada periode sebelumnya (t1). Jika terjadi korelasi, maka dinamakan ada problem autokorelasi (Imam Ghozali,2011). Misal, hasil uji autokorelasi menunjukkan nilai hitung Durbin-Watson. Nilai tersebut akan dibandingkan dengan nilai tabel Durbin-Watson dengan menggunakan nilai signifikansi 5\%, jumlah sampel 32, dan jumlah variabel independen $(\mathrm{k})=4$, maka didapatkan nilai dL dan dU. Nilai Durbin-Watson berada di daerah tidak ada autokorelasi positif atau negatif sehingga data terbebas dari persoalan autokorelasi.

\section{Uji Heteroskedastisitas}

Uji heteroskedastisitas digunakan untuk melihat apakah dalam sebuah model regresi terjadi ketidaksamaan varian dari residual satu pengamatan ke pengamatan yang lain. Model regresi yang baik adalah tidak terjadi Heteroskedastisitas Untuk mendeteksi adanya Heteroskedastisitas dapat dilakukan dengan menggunakan Uji Glesjer. Dengan hasil output SPSS, maka dapat diketahui bahwa bahwa angka probabilitas dari variabel BOPO, NPL, NIM, dan LDR dengan menunjukkan angka hasil uji, maka penelitian dinyatakan memenuhi asumsi 
homoskedastisitas atau tidak memiliki gangguan heteroskedastisitas, sehingga kriteria BLUE (Best Linier Unbiased Estimator) bisa terpenuhi.

\section{Uji Multikolinearitas}

Uji multikolinearitas bertujuan untuk menguji apakah model regresi ditemukan adanya korelasi antar variabel bebas (Imam Ghozali,2011). Pengujian adanya multikolinearitas dapat dilihat dari nilai tolerance value dan variance inflation value berada di atas 0,1 atau nilai VIF masing-masing variabel independen berada di bawah 10. Berdasarkan output SPSS, maka diperoleh nilai Tolerance dari variable-variabel independen yang menunjukkan nilai lebih dari 0,1 dan nilai VIF-nya kurang dari 10, sehingga dapat disimpulkan bahwa seluruh variabel independen terbebas dari persoalan multikolinearitas.

\section{Rancangan Analisis Dan Uji Hipotesis}

\section{Analisis Deskriptif}

Analisis deskriptif dengan pendekatan kuantitatif digunakan untuk meneliti pada populasi atau sampel tertentu, dengan pengumpulan data guna membedah masalah atau perbedaan data yang ada dengan melakukan pengukuran dalam bentuk data statistik.

\section{AnalisisVerifikatif}

\section{Analisis Regresi Berganda}

Analisis Data Model yang digunakan adalah regresi linier berganda (multiple regression analysis model) dengan model sebagai berikut:

$\mathrm{ROA}=\mathrm{a}+\mathrm{b} 1 \mathrm{BOPO}+\mathrm{b} 2 \mathrm{NIM}+\mathrm{b} 3 \mathrm{LDR}+\mathrm{b} 4 \mathrm{NPL}+\mathrm{e}$

Keterangan:

$\mathrm{ROA}=$ Return on Asset (Y)

$\mathrm{BOPO}=$ Biaya Operasi terhadap Pendapatan Operasi $\left(\mathrm{X}_{1}\right)$

$\mathrm{NIM}=$ Net Interest Margin $\left(\mathrm{X}_{2}\right)$

LDR = Loan to Deposit Ratio $\left(\mathrm{X}_{3}\right)$

$\mathrm{NPL}=$ Non Performing Loan $\left(\mathrm{X}_{4}\right)$

$\mathrm{a}=$ Konstanta

$\mathrm{e}=$ error

\section{Uji Koefisien Determinasi}

Hasil koefisien determinasi (Adjusted $\mathrm{R}$ square) diperoleh nilai atau kemampuan Biaya Operasional terhadap Pendapatan Operasional (BOPO), Net Interest Margin (NIM), Loans to Deposit Ratio (LDR) dan Non Performance Loan (NPL), dalam menjelaskan variasi Return on 
Assets (ROA) dengan melihat besaran Adjusted $R$ Square. Sedangkan nilai sisanya (100\%Adjusted R Square), dijelaskan oleh variabel lain diluar model.

\section{Uji Hipotesis}

\section{Uji Regresi Simultan (Uji F)}

Uji F pada dasarnya bertujuan untuk melihat kemampuan menyeluruh dari variabel bebas untuk dapat atau mampu menjelaskan tingkah laku atau keragaman variabel terhadap variabel terikat (Purwanto SH dan Suharyadi, 2009:238).

Dengan ketentuan pengambilan keputusan sebagai berikut:

- $\quad \mathrm{H}_{\mathrm{o}}$ diterima jika $\mathrm{F}_{\text {hitung }}<\mathrm{F}_{\text {tabel }}$ artinya semua variabel independen secara bersama-sama (simultan) tidak memiliki pengaruh signifikan terhadap variabel dependen.

- $\quad \mathrm{H}_{\mathrm{o}}$ ditolak jika $\mathrm{F}_{\text {hitung }}<\mathrm{F}_{\text {tabel }}$ artinya semua variabel independen secara bersama-sama (simultan) berpengaruh signifikan terhadap variabel dependen.

\section{Uji Regresi Parsial (Uji T)}

Uji Hipotesis dapat diuji dengan menggunakan uji t yang bertujuan untuk mengetahui pengaruh masing-masing variabel independen secara individu (parsial) terhadap variabel dependen

\section{HASIL PENELITIAN DAN PEMBAHASAN}

\section{Hasil Penelitian}

Penelitian ini menggunakan data sekunder, maka untuk menentukan ketepatan model perlu dilakukan pengujian asumsi klasik yang digunakan dalam penelitian ini. Sebelum pengujian asumsi klasik, dilakukan terlebih dahulu uji normalitas. Dan selanjutnya dilakukan uji asumsi klasik yang terdiri dari uji heteroskedastisitas, uji multikolinieritas, dan uji autokorelasi.

\section{Uji Normalitas}

Uji normalitas yang pertama dengan analisis grafik yaitu melihat grafik Normal P-Plot sebagaimana terlihat dalam gambar 4.2 berikut:

\section{Gambar 4.2 Grafik Normal P-Plot}




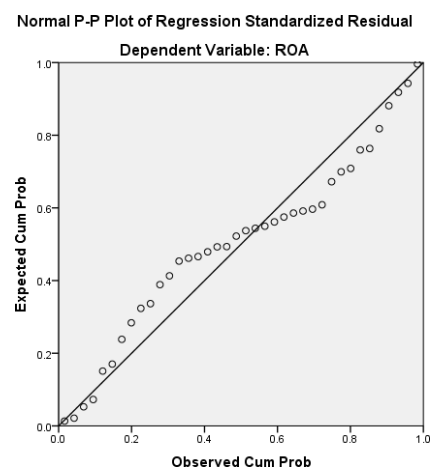

Sumber : Output IBM SPSS Statistics 23.0 (Data Sekunder, diolah 2021)

Dari gambar 4.2 Normal Probability Plot di atas menunjukkan bahwa data menyebar di sekitar garis diagonal dan mengikuti arah garis diagonal, maka dengan melihat hasil dari keduanya dapat dikatakan uji normalitas terpenuhi.

\section{Uji Heterokedastisitas}

Dengan melihat Scatter Plot dari trasnformasi data di gambar berikut :

\section{Gambar 4.3 Hasil Uji-Scatter Plot}

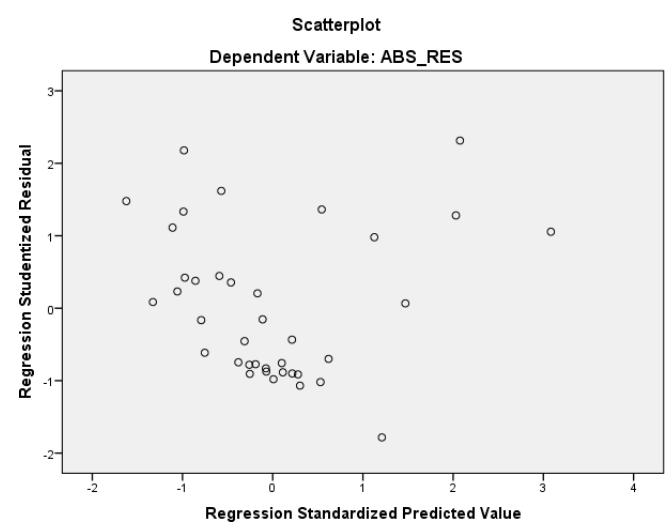

Sumber : Output IBM SPSS Statistics 23.0 (Data Sekunder, diolah 2021)

Berdasarkan pada gambar Scatter Plot tersebut dapat dilihat bahwa data tidak menumpuk atau membentuk pola garis tertentu dan data menyebar secara acak, sehingga dapat disimpulkan tidak terjadi heterokedastisitas.

\section{Uji Multikolinearitas}

Berdasarkan pada tabel 4.2 dapat diketahui bahwa variabel independen X1(BOPO), X2(NIM), X3(LDR), dan X4(NPL) dimana masing-masing memiliki nilai:

1. X1, variabel BOPO dengan nilai Tol sebesar $0,586>0,10$ dan VIF $1,707<10$.

2. $\mathrm{X} 2$, variabel NIM dengan nilai Tol sebesar $0,739>0,10$ dan VIF $1,353<10$.

3. X3, variabel LDR dengan nilai Tol sebesar 0,916>0,10 dan VIF 1,092<10.

4. X4, variabel NPL dengan nilai Tol sebesar $0,738>0,10$ dan VIF $1,355<10$. 
Dengan demikian dapat dipastikan bahwa tidak terdapat korelasi atau hubungan antar variabel independen karena nilai Tolerance dari masing-masing variable X1 sampai dengan X4 lebih besar dari 0,10 dan nilai Variance Inflation Factor (VIF) kurang dari 10.

\section{Uji Autokorelasi}

Metode pengujian dengan menggunakan Uji Durbin-Watson (Uji DW). Hasil uji autokorelasi . Nilai DW $=1.425$ lebih besar dari 0 dan nilai DW lebih kecil dari batas bawah (dl) yakni 2.2777, sehingga dapat disimpulkan tidak ada autokorelasi positif.

\section{Analisis Deskriptif}

Berdasarkan tabel 4.5, bahwa untuk variabel independen pada bank umum yang terdaftar di Bursa Efek Indonesia yaitu BOPO, NIM, LDR dan NPL didapatkan nilai minimum, maksimum dan rata-rata dari masing-masing variabel yaitu:

- Variabel BOPO dengan nilai minimum 61.220, nilai maksimum 135.104, dan nilai ratarata 89.54726

- Variabel NIM dengan nilai minimum 1.502, nilai maksimum 11.800, dan nilai rata-rata 5.09563

- Variabel LDR dengan nilai minimum 51.750, nilai maksimum 112.132, dan nilai ratarata 84.24284

- Variabel NPL dengan nilai minimum 0.012, nilai maksimum 4.516, dan nilai rata-rata 1.72284

Sedangkan variabel dependen pada bank umum yang terdaftar di Bursa Efek Indonesia yaitu ROA pada tabel 4.5 diatas menunjukkan nilai minimum -4.426, nilai maksimum 4.296 dan nilai rata-rata 1.17711 dari data statistik deskriptif hasil output spss.

\section{Analisis Verifikatif}

\section{Analisis Regresi Linier Berganda}

Pengelolaan data penelitian ini menggunakan analisis regresi linier berganda, dilakukan beberapa tahap untuk mencari pengaruh dari variabel independen (BOPO, NIM, LDR dan NPL) terhadap variabel dependen (ROA).

Dengan melihat tabel diatas, dapat disusun persamaan regresi linier berganda sebagai berikut :

$$
\begin{gathered}
\text { Y }=9,680+(-0,097) X 1+0,145 \text { X2 + }(-, 006) X 3+(-0,009) X 4 \\
\text { ROA }=9,680+(-0,097) \text { BOPO + 0,145 NIM + (-0,006) LDR + (-0,009) NPL }
\end{gathered}
$$


Dari persamaan regresi diatas mempunyai makna sebagai berikut :

1. Konstanta sebesar 9,680 menyatakan bahwa jika variabel independen (BOPO, NIM, LDR dan NPL) dianggap konstan, maka rata-rata ROA 9,680.

2. Efisiensi Operasi atau BOPO sebesar -0,097. Nilai koefisien yang negatif menunjukkan bahwa efisiensi operasi (BOPO) berpengaruh negatif terhadap kinerja bank (ROA) untuk Bank Umum yang terdaftar di BEI selama tahun pengamatan 2016-2020. Hal ini menunjukkan bahwa setiap kenaikan satu satuan dari BOPO akan menyebabkan kinerja bank (ROA) mengalami penurunan 0,097 kalinya begitu pula sebaliknya.

3. Risiko pasar atau NIM sebesar 0,145. Nilai koefisien yang positif menunjukkan bahwa risiko pasar (NIM) berpengaruh positif terhadap kinerja bank (ROA) untuk Bank Umum yang terdaftar di BEI selama tahun pengamatan 2016-2020. Hal ini menunjukkan bahwa setiap kenaikan satu satuan dari risiko pasar (NIM) akan menyebabkan kinerja bank (ROA) mengalami kenaikan 0,145 kalinya begitu pula sebaliknya.

4. Likuiditas atau LDR sebesar -0,006. Nilai koefisien yang negatif menunjukkan bahwa likuiditas (LDR) berpengaruh negatif terhadap kinerja bank (ROA) untuk Bank Umum yang terdaftar di Bursa Efek Indonesia selama tahun pengamatan 2016-2020. Hal ini menunjukkan bahwa setiap kenaikan satu satuan dari LDR akan menyebabkan kinerja bank (ROA) mengalami penurunan 0,006 kalinya begitu pula sebaliknya.

Risiko kredit atau NPL sebesar -0,009. Nilai koefisien yang negatif menunjukkan bahwa risiko kredit (NPL) berpengaruh negatif terhadap kinerja bank (ROA) untuk Bank Umum yang terdaftar di Bursa Efek Indonesia selama tahun pengamatan 2016-2020. Hal ini menunjukkan bahwa setiap kenaikan satu satuan dari NPL akan menyebabkan kinerja bank (ROA) mengalami penurunan 0,009 kalinya begitu pula sebaliknya.

\section{Pembahasan}

\section{Pembahasan Deskriptif}

Berdasarkan hasil analisis data dan pengujian statistik deskriptif terhadap masingmasing hipotesis dalam penelitian dimana dalam data hasil output spss menyajikan data deskriptif statistik yang terdapat nilai minimum, nilai maksimun dan nilai rata-rata serta nilai standar deviasi dari masing-masing variabel penelitian . Untuk variabel independen pada bank umum yang terdaftar di Bursa Efek Indonesia yaitu BOPO, NIM, LDR dan NPL didapatkan nilai minimum, nilai maksimum dan nilai rata-rata dari masing-masing variabel. 
Pada tabel 4.5 diatas menunjukkan bahwa Beban Operasional terhadap Pendapatan Operasional memiliki nilai terendah (minimum) $61.22 \%$, nilai tertinggi (maksimum) 135.104\%, dan memiliki nilai rata-rata (mean) $89.54726 \%$ dengan standar deviasi Beban Operasional terhadap Pendapatan Operasional sebesar $17.190863 \%$ atau bisa dikatakan sebaran Beban Operasional terhadap Pendapatan Operasional terdistribusi secara normal.

Kemudian pada tabel 4.5 diatas juga menunjukkan bahwa Net Interest Margin memiliki nilai terendah (minimum) 1.502\%, nilai tertinggi (maksimum) 11.800\%, dan nilai rata-rata (mean) $5.09563 \%$ dengan standar deviasi nilai NIM $1.965453 \%$ bisa dikatakan sebaran Net Interest Margin terdistribusi secara normal.

Pada tabel 4.5 diatas menunjukkan bahwa Loan to Deposit Ratio memiliki nilai terendah (minimum) 51.750\%, nilai tertinggi (maksimum) $112.132 \%$, dan nilai rata-rata (mean) $84.24284 \%$ dengan standar deviasi nilai Loan to Deposit Ratio $12.580095 \%$ maka dapat dikatakan Loan to Deposit Ratio terdistribusi secara normal.

Sedangkan pada variabel Non Performance Loan dengan melihat tabel 4.5 diatas juga menunjukkan bahwa Non Performance Loan memiliki nilai terendah (minimum) $0.012 \%$, nilai tertinggi (maksimum) $4.516 \%$, dan nilai rata-rata (mean) $1.72284 \%$ dengan standar yang baik yang telah ditetapkan Bank Indonesia adalah tidak lebih dari 5\%, maka dapat dikatakan bahwa sebaran Non Performance Loan terdistribusi secara normal.

Pada tabel 4.5 diatas menunjukkan bahwa Return On Asset memiliki nilai terendah (minimum) $-4.426 \%$, nilai tertinggi (maksimum) 4.296\%, dan nilai rata-rata (mean) $1.17711 \%$ dengan standar Return On Asset menurut SE BI no 15/43/DPNP tanggal 21 Oktober 2013 yaitu minimal nilai $R O A$ diangka 1,5\%, maka dapat dikatakan bahwa sebaran Return On Asset terdistribusi secara normal.

\section{Pembahasan Verifikatif}

Penelitian ini menggunakan metode analisis regresi linier berganda dalam analisis verifikatif yang pada dasarnya ingin menguji kebenaran melalui pengumpulan data di lapangan yang bersifat menguji kebenaran dari suatu hipotesis yang dilakukan dan bertujuan untuk mengetahui pengaruh variabel Beban Operasional terhadap Pendapatan Operasional (BOPO), Net Interest Margin (NIM), Loan to Deposit (LDR) dan Non Performance Loan (NPL) terhadap Return On Asset (ROA) baik secara parsial maupun simultan.

Dari hasil pengujian secara parsial variabel BOPO terhadap ROA pada tabel 4.9 dan tabel 4.10 diatas diperoleh nilai t-hitung sebesar -24,828 dan kinerja bank dengan probabilitas signifikansi 0,000. Dimana kinerja bank nilai probabilitas signifikansi 0,000 ini signifikan pada 
tingkat signifikansi 0,05 karena lebih kecil dari 0,05. Sehingga dapat disimpulkan bahwa BOPO tidak berpengaruh secara negatif dan signifikan terhadap ROA sebesar 97,8\%. Dari keterangan diatas dapat disimpulkan untuk hipotesis ke 1 bahwa BOPO tidak berpengaruh negatif dan signifikan terhadap ROA. Hal ini menunjukkan bahwa pengaruh signifikan variabel BOPO terhadap variabel ROA secara parsial tidak berpengaruh negatif dan signifikan.

Dengan kata lain ini menunjukkan bahwa manajemen perusahaan telah lebih meningkatkan kinerja bank dengan nilai efisiensi operasi yang terukur jelas, sesuai dengan tujuan manajemen keuangan dengan nilai dari efisiensi operasi tersebut masih dalam batas standarisasi perbankan yang sehat sehingga dapat membuat para investor tertarik untuk berinvestasi dan sekaligus akan merasakan keuntungan yang lebih besar dari modal yang mereka keluarkan.

\section{KESIMPULAN DAN IMPLIKASI}

Hasil pembahasan atas pengolahan data dan berdasarkan tinjauan pustaka serta metodologi yang digunakan dalam penelitian ini, dapat diambil kesimpulan sebagai berikut :

1. Bahwa secara keseluruhan pertumbuhan bank dengan rasio BOPO, NIM, LDR dan NPL sebagai variable independen yang mempengaruhi ROA dan ROA sebagai variabel dependent pada Bank Umum yang Terdaftar di Bursa Efek Indonesia masih terdapat batasan-batasan yang belum dapat terpenuhi secara sempurna namun tetap dalam batas kewajaran dan dalam koridor yang aman karena masih sesuai dengan ketentuan yang ada pada Bank Indonesia serta operasionalisasi perbankan tersebut dalam pengawasan OJK (Otorisasi Jasa Keuangan). Dengan begitu, seluruh industri perbankan yang telah terdaftar di Bursa Efek Indonesia akan berupaya menjaga kondisi perusahaan agar tetap bisa beroperasi di pasar terbuka dengan mematuhi segala ketentuan-ketentuan yang berlaku bagi perusahaan, baik di pasar perekonomian Indonesia maupun di pasar global. Tingkat ROA pada Bank Umum yang Terdaftar di Bursa Efek Indonesia memiliki rata-rata 1,1771\% dan angka ini sudah diatas nilai ideal dari Bank Indonesia yaitu 1,5\%.

Masing-masing Bank juga mempunyai keunggulan spesifik yang dapat dioptimalkan guna meningkatkan kinerja seperti keunggulan teknologi, service, produk, jaringan (network), sumber daya manusia, dan lain-lain. Keunggulan-keunggulan utama/spesifik dari tiap bank dapat dioptimalkan sehingga menjadi suatu sinergi yang pada akhirnya berdampak pada peningkatan Return on Assets .

2. Pengaruh secara parsial BOPO, NIM, LDR dan NPL terhadap ROA pada Bank Umum yang Terdaftar di Bursa Efek Indonesia yaitu: 
a. Efisiensi Operasi yang diukur oleh perbandingan total biaya operasi dengan total pendapatan operasi (BOPO) mempunyai pengaruh negatif dan signifikan terhadap ROA karena semakin efisien bank maka akan membuat ROA bertambah tinggi pada Bank Umum yang Terdaftar di Bursa Efek Indonesia periode tahun 2016-2020, sehingga hal ini membuktikan sesuai terhadap teori dan penelitian terdahulu.

b. Risiko pasar yang diukur dengan NIM secara statistik mempunyai pengaruh positif dan signifikan terhadap ROA, dengan begitu semakin besar NIM maka akan memperkecil risiko pasar bank pada Bank Umum yang Terdaftar di Bursa Efek Indonesia periode tahun 2016-2020, hal ini membuktikan sesuai terhadap teori dan penelitian terdahulu.

c. Likuiditas yang diproksi dengan Loan to Deposit Ratio (LDR), secara statistik tidak signifikan berpengaruh terhadap ROA hal ini terjadi disebabkan karena pada beberapa bank mengalami akumulasi dana (overlikuid) dan mengalami kesulitan dalam menyalurkan dana sehingga hal ini tidak meningkatkan ROA pada Bank Umum yang Terdaftar di Bursa Efek Indonesia periode tahun 2016-2020. Hal ini membuktikan sesuai terhadap teori dan penelitian terdahulu

d. Risiko kredit yang diukur dengan NPL secara statistik mempunyai pengaruh negatif dan tidak signifikan terhadap ROA Hal ini disebabkan karena setiap kenaikan outstanding pinjaman diberikan, bank wajib membentuk cadangan aktiva, sehingga memperbesar biaya cadangan

pinjaman diberikan dan ini tentunya akan meningkatkan risiko kredit pada Bank Umum yang Terdaftar di Bursa Efek Indonesia periode tahun 2016-2020, hal ini membuktikan kesesuaian terhadap teori dan penelitian terdahulu

Secara simultan rasio BOPO, NIM, LDR, dan NPL berpengaruh terhadap ROA sebesar 97,4\% yang berarti sangat kuat pada Bank Umum yang Terdaftar di Bursa Efek Indonesia periode tahun 2016-2020. Hal ini juga membuktikan terhadap teori dan penelitian terdahulu

Berdasarkan simpulan dan pembahasan pada bab-bab sebelumnya, maka dikemukakan beberapa saran yang diharapkan dapat berguna bagi pihak terkait sebagai berikut:

1. Bagi Perusahaan

Pada penelitian ini secara parsial Efisiensi Operasi (BOPO), Net interest Margin, Loan to Deposit Ratio, dan Non Performance Loan mempunyai pengaruh terhadap terhadap Return On Asset (ROA) dengan tingkat pengaruh 97,4\%. Dengan demikian, agar ROA bank semakin baik maka para pengambil kebijakan perlu memperhatikan perkembangan rasio BOPO, NIM, LDR dan NPL dari waktu ke waktu agar tidak terjadi 
penurunan dalam penguasaan pasar serta para pengambil kebijakan perlu menjaga agar persentase masing-masing rasio tersebut tidak menurun dan diharapkan justru terjadi peningkatan dari waktu ke waktu.

Hal ini menunjukkan bahwa perusahaan perlu memperhatikan faktor kesehatan bank tersebut sehingga dapat menarik pihak investor untuk menanamkan modalnya sehingga permintaan saham akan tinggi, harga saham dan profitabilitas perusahaan pun meningkat.

2. Bagi Investor dan Pelaku Pasar

Bagi investor diharapkan untuk melakukan pertimbangan dalam melakukan investasi dengan menganalisis terlebih dahulu ukuran kesehatan bank melalui Efisiensi Operasi (BOPO), Net interest Margin, Loan to Deposit Ratio, dan Non Performance Loan, karena dalam penelitian ini rasio tersebut mempunyai pengaruh positif terhadap kinerja perbankan. Dengan memperhatikan faktor-faktor yang mempengaruhi kinerja bank diharapkan investor dapat menyusun portofolio investasi secara optimal memaksimalkan return dengan tingkat resiko tertentu

3. Bagi Peneliti Selanjutnya

Penelitian ini memiliki keterbatasan penelitian yaitu periode penelitian yang tidak ada jeda tahun antara rasio pada variabel X dengan ROA pada variabel Y. Selain itu pada jumlah variable yang digunakan dalam penelitian ini, tidak semua diteliti atau ditampilkan.

Untuk penelitian mendatang, penulis juga menyarankan kepada peneliti selanjutnya untuk menambahkan variabel lain yang diduga mempunyai pengaruh terhadap kinerja bank, seperti CAR atau tingkat kemampuan / kecukupan modal minimum perusahaan.

Selain itu juga diharapkan untuk menambah periode tahun penelitian, menambahkan variabel Operational Risk yang disesuaikan dengan objek penelitian yang digunakan serta pada penelitian mendatang dapat menggunakan objek penelitian yang berbeda dengan penelitian ini. 


\section{DAFTAR PUSTAKA}

A.A Yogi Prasanjaya \& I Wayan Ramantha, (2013). Analisis Pengaruh Rasio CAR, BOPO, LDR Dan Ukuran Perusahaan Terhadap Profitabilitas Bank Yang Terdaftar di BEI, EJurnal Akuntansi Universitas Udayana 4.1

Agnes Sawir (2005). Analisis Kinerja Keuangan dan Perencanaan Keuangan Perusahaan, Jakarta : PT. Gramedia Pustaka Utama. 2005

Bambang Sudiyatno dan Rini Setiyowati, (2012). Pengaruh BOPO, NPL, NIM dan CAR Terhadap Kinerja Keuangan Bank (Studi Pada Bank-Bank Yang Listed di Bursa Efek Indonesia). Dinamika Akuntansi, Keuangan dan Perbankan, Vol 1, No 1.

Bambang Sudiyatno dan Jati Suroso, (2010). Analisis Pengaruh Dana Pihak Ketiga, BOPO, CAR dan LDR Terhadap Kinerja Keuangan Pada Sektor Perbankan yang Go Public di Bursa Efek Indonesia (BEI) Periode 2005-2008).

Begumhan Ozdincer \& Cenktan Ozyildirim, (2006). Determining Factors Of Bank Performance Based On Return On Solvency And Efficiency: A Study Of Turkish Banks.

Dendawijaya, Lukman. 2005. Manajemen Perbankan. Bogor: Ghalia Indonesia.

Didik Purwoko dan Bambang Sudiyatno, (2013). Faktor-Faktor Yang Mempengaruhi Kinerja Bank (Studi Empirik Pada Industri Perbankan di Bursa Efek Indonesia).

Dahlan Siamat, 1999. Manajemen Lembaga Keuangan, Lembaga Penerbit FEUI, Edisi Dua, Jakarta.

Edhi Satriyo Wibowo dan Muhammad Syaichu, (2013). Analisis Pengaruh Suku Bunga, Inflasi, CAR, BOPO, NPF Terhadap Profitabilitas Bank Syariah.

Fahmi, Irfan. 2011. Analisis Laporan Keuangan. Bandung: Alfabeta

Farah Margaretha dan Letty, (2017). Faktor-Faktor Yang Memengaruhi Kinerja Keuangan Perbankan Indonesia.

Ferdi Rindhatmono, (2005). Analisis Faktor-faktor yang Mempengaruhi Profitabilitas Bank Pasca Merger di Indonesia. Tesis Pasca Sarjana, Magister Manajemen Universitas Diponegoro Semarang. 
FX Sugiyanto, Prasetiono, Teddy Haryanto, 2002. Manfaat Indikator - Indikator Keuangan Dalam Pembentukan Model Prediksi Kondisi Kesehatan Perbankan, Jurnal Bisnis Strategi, Vol. 10, Program Magister Manajemen Universitas Diponegoro.

Ghozali I. 2006. Aplikasi Analisis Multivariate dengan Program SPSS, Semarang (ID): BP Universitas Diponegoro.

Hasan, M Iqbal. 2002. Pokok-pokok Materi Metodologi Penelitian dan Aplikasinya. Jakarta: Ghalia Indonesia.

Hasan M Fadhil, Listiyanto E. Analysis of Factors Affecting Banking Intermediation in Indonesia. MAC Praque Consulting: 368-374.

Hampton, John J. 2006, Financial Decision Making, Concepts, Problems nd Chase, Ed ke-4. India (IND): Prentice hall.

Hariani MDPP. 2012. Faktor-faktor yang mempengaruhi nilai perusahaan (studi Pada perusahaan yang terdaftar di Jakarta Islamic Index 2007-2010). Jakarta (ID); Universitas Sumatra Utara.

Haryanto, Sugeng. 2016. Profitability Identification Of National Banking Through Credit, Capital, Capital Structure, Efficiency, And Risk. Jurnal Dinamika Manajemen: 11-21.

Hermuningsih, Sri. 2013. Pengaruh Profitabilitas, Growth Opportunity, Struktur Modal Terhadap Nilai Perusahaan Pada perusahaan Publik Di Indonesia. Jurnal Buletin Ekonomi Moneter Dan Perbankan: 128-147.

Hidayat M. (2014). Pengaruh rasio kesehatan perbankan terhadap nilai Perusahaan (studi kasus pada perbankan yang terdaftar di BEI). Jurnal Ekonomi dan Informasi Akutansi. 4(1): 41-47.

Husnan S.pudjiastuti E. 2004. Dasar-dasar manajemen keuangan .yogyakarta (ID):UPP AMP YKPN.

Husein Umar, 2000. Research Methods in Finance and Banking, Bussines Research Center, Jakarta.

Imam Ghozali, (2005). Aplikasi Analisis Multivariate dengan Program SPSS, Badan Penerbit Universitas Diponegoro, Semarang.

Kartika Wahyu Sukarno dan Muhammad Syaichu, (2006). Analisis Faktor-faktor Yang Mempengaruhi Kinerja Bank Umum di Indonesia.

Kasmir. 2011. Bank lembaga keuangan lainnya ED rev 2008. Jakarta (ID): Raja grafindo press. 
Laporan Keuangan Publikasi Bursa Efek Indonesia tahun 2016-2020

Luh Eprima Dewi, dkk, (2015). Analisis Pengaruh NIM, BOPO, LDR, dan NPL Terhadap Profitabilitas (Studi Kasus Pada Bank Umum Swasta Nasional Yang Terdaftar Pada Bursa Efek Indonesia Periode 2009-2013).

Lukman S . 2000. Manajemen Keuangan Jakarta (ID): Raja grafindo persada.

Made Ria Anggreni dan I Made Sadha Suardika, (2014). Pengaruh Dana Pihak Ketiga, Kecukupan Modal, Risiko Kredit dan Suku Bunga Kredit Pada Profitabilitas.

Maharani Ika Lestari dan Toto Sugiharto, (2007). Kinerja Bank Devisa dan Faktor-Faktor Yang memengaruhinya.

Muh. Sabir M, et all, (2012). Pengaruh Rasio Kesehatan Bank Terhadap Kinerja Keuangan Bank Umum Syariah dan Bank Konvensional di Indonesia.

Mudrajad Kuncoro, 2003. Metode Riset Untuk Bisnis \& Ekonomi; Bagaimana Meneliti dan Menulis Tesis , Januari, Edisi 1, Penerbit Erlangga, Jakarta.

Mudrajad Kuncoro,2004. Metode Kuantitatif , Juni,Edisi 2, UPP AMP YKPN, Yogjakarta.

Nurul Maulidya Latifah., Rodhiyah., dan Saryadi, (2012). Pengaruh Capital Adecuacy Ratio (CAR), Non Performance Loan (NPL), dan Loan to Deposit Ratio (LDR) Terhadap Return on Asset (ROA) (Studi Kasus pada Bank Umum Swasta Nasional Devisa Go Public di Bursa Efek Indonesia Periode 2009 - 2010). Jurnal Ilmu Administrasi Bisnis. Universitas Diponegoro - Semarang.

Peraturan Bank Indonesia, 2003. PBI No. 5/8/PBI/2003 tentang Penerapan Manajemen Resiko Bagi Bank umum .

Priyatno, Duwi. 2010. Paham Analisa Statistik Data Dengan SPSS. Yogyakarta: MediaNom. Sitanggang, J P. 2014. Manajemen Keuangan Perusahaan ED.2. Jakarta: Mitra Wacana Medika.

Sjahrial, Dermawan. 2012. Pengantar Manajemen Keuangan. Jakarta: Mitra Wacana Medika. Slamet Riadi, 2004. Banking Assets And Liability Management, Edisi 2, Lembaga Penerbit Universitas Indonesia, Jakarta.

Sofyan, Harahap S 2007. Analisis Kritis atas Laporan Keuangan. Jakarta (ID) Ranja Grafindo Persada. 
Soliha E, Taswan 2002. Pengaruh kebijakan hutang terhadap nilai perusahaan Serta beberapa faktor yang mempengaruhinya. Jurnal Bisnis dan Ekonomi 9(2): 149-163

Suad Husnan, MBA, 2017. Manajemen Keuangan - Teori dan Penerapannya, Buku 1 cetakan 2017, BPFE, Yogjakarta.

Sudaryono. 2014. Pengantar Manajemen: Teori Dan Kasus. Jakarta: Buku Seru.

Sugiyono .2013. Memahami Penelitian Kualitatif Bandung(ID): Alfabeta.

Suharyadi dan Purwanto, 2009. Statistika Untuk Ekonomi Dan Keuangan Modern Edisi 2 Buku 2. Jakarta: Salemba Empat

Sujoko, Soebintoro U. 2007. Pengaruh struktur kepemilikan, leverage, faktor Intern, dan faktor ekstren terhadap nilai perusahaan (studi empirik pada Perusahaan manufaktur dan non manufaktur di bursa Efek Jakarta). Jurnal Manajemen dan Kewirausahaan. 9(1): 41-49

Supriyadi Didit, (2018). Integrasi, Pendidikan, dan Kinerja: Studi Empirik pada Perbankan. Bandung: Manggu Makmur Tanjung Lestari.

Syamsul Hadi, (2006). Metodologi Penelitian Kuantitatif untuk Akuntansi \& Keuangan, Edisi Pertama, Cetakan Pertama, Ekonisia Kampus UII, Yogyakarta.

Taswan, (2002). Manajemen Perbankan Konsep, Teknis \& Aplikasi, STIM YKPN, Yogyakarta.

Taswan, M. 2010. Manajemen Perbankan: Konsep, Teknik dan Aplikasi. Yogyakarta: UPP STIM YKPN Yogyakarta.

Tampubolon, Manahan P. 2013. Manajemen Keuangan (Finance Management). Jakarta: Mitra Wacana Medika.

Teguh P, Mulyono. 2001. Manajemen Perkreditan Komersil. Yogyakarta: BPFE.

Triandaru S, Budisantoso T. 2004. Bank dan Lembaga Keuangan Lain. Jakarta (ID): Salemba Empat.

Wawan Prasetyo, (2015). Analisis Faktor-Faktor Yang Mempengaruhi Profitabilitas Perbankan. 
Wisnu Mawardi, (2004). Analisis Faktor-Faktor Yang Mempengaruhi Kinerja Keuangan Bank Umum di Indonesia : Studi Kasus Pada Bank Umum Dengan Total Asset Kurang Dari 1 Trilyun, Tesis S2, Fakultas Pascasarjana, Universitas Diponegoro, Semarang.

https://www.ojk.go.id/id/kanal/perbankan/data-dan-statistik/statistik-perbankanindonesia/Pages/Statistik-Perbankan-Indonesia---Desember-2020 